Syntax Literate: Jurnal Ilmiah Indonesia p-ISSN: 2541-0849

e-ISSN: 2548-1398

Vol. 5, No. 7, Juli 2020

\title{
COST EFFECTIVENESS ANALYSIS PENGGUNAAN HEPATOPROTEKTOR PADA TERAPI TUBERKULOSIS DI RS PARU CISARUA, BOGOR
}

\author{
Lukluk Utaminingsih, Delina Hasan dan Alvin Kosasih \\ Fakultas Farmasi Universitas Pancasila Jakarta \\ Email : lukluk.utami@gmail.com,delina.hasan@uinjkt.ac.id dan \\ alvinkosasih@gmail.com
}

\section{Abstract}

Alternative use of hepatoprotector in tuberculosis therapy with the incidence of drug-induced hepatitis (DIH) requires economic pharmacological studies, especially Cost Effectiveness Analysis. The purpose of this study is to compare the cost effective use of hepatoprotector to treat DIH in the treatment of TB. The method used was a cohort design and prospective data collection from medical records of inpatient TB patients with DIH and detailed data on treatment costs from the financial department of Cisarua Lung Hospital, Bogor. A sample of 90 patients was randomly divided into double blind, group 1 using placebo, group 2 using curcumin and group 3 using lecithin. The parameters measured were the value of serum ALT levels on day 5, direct costs and indirect costs. The results showed the effectiveness of hepatoprotector in TB patients with the highest DIH in reducing ALT levels to normal values ( $<51 I U / L)$ was a placebo for 11 patients, curcumin for 8 patients, and lecithin for 2 patients. Cost effectiveness based on ACER values on placebo, curcumin and lecithin sequentially was Rp 4,120,342.23 / patient, Rp5,571,803.76 / patient and Rp.25,444,523.64 / patient. The use of curcumin as a hepatoprotector is more cost effective than lecithin but the incidence of DIH in TB management will be controlled by itself without hepatoprotector administration if the causative drug is stopped.

Keywords : Cost effectiveness analysis; hepatoprotector; tuberculosis

\section{Abstrak}

Alternatif penggunaan hepatoprotektor pada terapi tuberkulosis dengan kejadian hepatitis imbas obat (DIH) memerlukan studi farmako ekonomi terutama Cost Efectiveness Analysis. Tujuan penelitian ini membandingkan cost effective pemakaian hepatoprotektor untuk mengatasi DIH pada pengobatan TB. Metode dengan desain kohort dan pengambilan data secara prospektif dari rekam medis penderita TB rawat inap yang mengalami DIH dan data rincian biaya pengobatan dari bagian keuangan RS Paru Cisarua Bogor. Sampel 90 pasien dibagi secara acak buta ganda yaitu kelompok 1 menggunakan plasebo, kelompok 2 menggunakan kurkumin dan kelompok 3 menggunakan lesitin. Parameter yang diukur adalah nilai kadar serum ALT hari ke 5, biaya langsung dan biaya tidak langsung. Hasil penelitian menunjukkan efektivitas hepatoprotektor pada pasien TB dengan DIH paling tinggi dalam menurunkan kadar ALT sampai nilai normal $(<51 \mathrm{IU} / \mathrm{L})$ adalah plasebo sebanyak 11 pasien, kurkumin sebanyak 8 pasien, dan lesitin sebanyak 2 
pasien. Efektivitas biaya berdasarkan nilai ACER pada plasebo, kurkumin dan lesitin secara berurutan adalah Rp 4.120.342,23/pasien, Rp 5.571.803,76/pasien dan Rp 25.444.523,64/pasien. Penggunaan kurkumin sebagai hepatoprotektor lebih cost effective dibandingkan lesitin akan tetapi kejadian DIH pada tatalaksana TB akan terkendali dengan sendirinya tanpa pemberian hepatoprotektor jika obat penyebab dihentikan.

Kata kunci : Cost effectiveness analysis; hepatoprotektor; tuberkulosis.

\section{Pendahuluan}

Tuberkulosis (TB) masih menjadi salah satu penyakit menular yang paling mematikan di dunia dan dapat menyerang individu dari semua tingkat sosial dalam masyarakat ((Kemenkes RI), 2016). Data WHO menunjukkan sekitar 85\% kasus TB berhasil diobati, namun ada beberapa efek samping yang terkait dengan pengobatan, antara lain hepatotoksisitas, reaksi kulit, gangguan pencernaan dan neurologis.

Hepatotoksisitas merupakan efek samping paling umum dari semua reaksi obat yang merugikan pada $11 \%$ pasien yang diobati dengan kombinasi isoniazid, rifampisin, dan pirazinamid (Wang et al., 2016). Berdasarkan studi literatur diketahui bahwa ada banyak faktor yang meningkatkan risiko terjadinya hepatotoksisitas imbas OAT. Di antara faktor tersebut yaitu usia, jenis kelamin, genetik, infeksi hepatitis C atau B, infeksi HIV, status gizi, konsumsi alkohol, bersamaan dengan konsumsi obat hepatotoksik lainnya dan kadar SGPT awal yang meningkat (Luthariana, Karjadi, Hasan, \& Rumende, 2017).

Data di RS Paru dr. M. Goenawan Partowidigdo, Cisarua, Bogor pada bulan November tahun 2016 sampai November 2017 terdapat 10.750 kunjungan pasien rawat jalan penderita TB paru dan 2.070 pasien TB yang rawat inap. Dari 10.750 pasien rawat jalan, terdapat 631 pasien TB paru dengan hepatitis imbas obat karena obat anti tuberkulosis. Dan dari 2.070 pasien TB rawat inap, terdapat 329 pasien TB paru dengan hepatitis imbas obat karena obat anti tuberkulosis (Bil et al., 2018).

Hepatitis imbas obat dapat mengurangi efektivitas obat anti tuberkulosis karena dapat mengurangi kepatuhan (adherence) penderita secara signifikan dan pada akhirnya dapat mengarah pada kegagalan terapi dan resistensi obat. Jika diabaikan hepatitis imbas obat yang timbul akan memperburuk keadaan umum penderita dan menyebabkan penundaan pengobatan sehingga berakibat fatal (Ramappa \& Aithal, 2013). Berdasarkan evaluasi efek terapi obat anti tuberkulosis (OAT) di Rumah Sakit Umum Daerah Dr. Saiful Anwar Malang pada tahun 2013 yang melibatkan sebanyak 460 pasien tuberkulosis (TB) yang menerima directly observed treatment strategy (DOTS), hasil penelitian diperoleh 25 pasien yang mengalami hepatitis akibat OAT dengan nilai insiden sebesar 5,4\% (Rifai, Herlianto, Mustika, Pratomo, \& Supriono, 2015).

Pada era pelayanan kesehatan menggunakan sistem jaminan kesehatan nasional saat ini, kelompok hepatoprotektor tidak masuk dalam standar obat nasional yaitu Formularium Nasional. Dari perspektif lembaga pembayar yaitu BPJS, hepatoprotektor tidak masuk dalam manfaat yang dijamin karena tidak ada dalam penatalaksanaan 
pengobatan tuberkulosa, panduan praktik klinik ataupun Formularium Nasional karena efikasi hepatoprotektor belum ada evidence basenya. Akan tetapi bertentangan dengan kenyataan dimana para klinisi memberikan hepatoprotektor dalam upaya mencegah dan mengatasi kejadian hepatitis imbas obat. Dari perspektif individu yaitu pasien, di satu sisi ada kebutuhan untuk mendapatkan terapi sesuai dengan yang diberikan oleh klinisi, akan tetapi ada harapan untuk tidak harus iuran biaya atau mengeluarkan biaya out of pocket. Oleh sebab itu diperlukan penelitian tentang cost effectiveness analysis penggunaan hepatoprotector untuk mengatasi terjadinya hepatitis imbas obat pada terapi tuberkulosis di RS Paru dr. M. Goenawan Partowidigdo, Cisarua, Bogor. Bogor. Dengan memperhatikan efektivitas dan biaya terapi tersebut, penelitian ini dapat menjadi bahan pertimbangan rumah sakit dalam membuat kebijakan atau clinical pathway tuberkulosis paru dengan hepatitis imbas obat.

\section{Metode Penelitian}

Penelitian ini menggunakan metode Cost Efectiveness Analysis desain kohort dengan penelusuran data secara prospektif. Lokasi penelitian dilakukan di RS Paru dr.M. Goenawan Partowidigdo Cisarua, Bogor. Populasi penelitian ini adalah penderita tuberkulosis paru yang sedang dalam terapi OAT dengan hepatitis imbas obat di RS Paru dr.M. Goenawan Partowidigdo Cisarua, Bogor, sebesar 281 pasien. Sampel sebesar 90 pasien dibagi menjadi tiga kelompok yaitu 30 sampel kelompok dengan pemberian obat hepatoprotektor kurkumin, 30 sampel kelompok dengan pemberian obat hepatoprotektor lesitin, dan 30 sampel kelompok dengan pemberian plasebo/tanpa pemberian obat hepatoprotektor. Data dalam penelitian ini merupakan data sekunder yang diperoleh dari rekam medis pasien, hasil laboratorium dan billing pasien. Subjek penelitian ini adalah pasien TB Paru yang sedang dalam terapi OAT dengan hepatitis imbas obat serta mendapatkan hepatoprotektor (kurkumin, lesitin maupun placebo). Penentuan subjek penelitian untuk tiap kelompok perlakuan dilakukan dengan randomisasi buta ganda. Kemudian data diolah dan dianalisa secara deskriptif dan statistik, karakteristik pasien digambarkan dalam nilai rata-rata (mean) dan prosentase.

\section{Hasil dan Pembahasan}

Komite Etik Penelitian Kesehatan Fakultas Kedokteran Universitas Indonesia dengan Nomor : 0773/UN2.F1/Etik/2018 telah memberikan keterangan lolos kaji etik untuk penelitian ini.

\section{Analisis Univariat}

\section{a. Karakteristik Subyek Penelitian}

Karakteristik pasien dalam penelitian ini antara lain jenis kelamin lakilaki ada 53 orang atau 58,9\% lebih banyak dibandingkan jenis kelamin perempuan. yaitu 37 orang atau 41,1\%. Persentase penderita tuberkulosis dengan hepatitis imbas obat pada jenis kelamin laki-laki cenderung lebih banyak dibandingkan dengan perempuan, hal ini sejalan dengan penelitian Nurul dkk. (2014), yang dikutip oleh Dewi, Ayu Sintya (2018), menyebutkan 
bahwa penderita TB dengan hepatitis imbas obat lebih banyak diderita oleh laki-laki disebabkan oleh kebiasaan merokok dan konsumsi alkohol (Sintya, 2018); (Rahayu, 2018). Sesuai juga dengan penelitian Lies Luthariana dkk bahwa dari 33 kasus yang ditemukan, 91\% subjek berjenis kelamin laki-laki (Luthariana et al., 2017). Dari kelompok umur, paling banyak antara umur 17 sampai 25 tahun sebanyak 22 orang atau 24,4\%, sedangkan yang sedikit adalah umur di atas 65 tahun sebanyak 7 orang atau $7,8 \%$.

Karakteristik usia subyek penelitian yang dominan antara 17 sampai 25 tahun. Menurut Debarhavi, 2012 pada pasien remaja terdapat faktor pemicu hepatitis imbas obat selain keturunan yaitu penggunaan obat-obatan penginduksi hati, kekurangan nutrisi, polifarmasi, HIV/AIDS dan penderita hepatitis $\mathrm{B}$ atau hepatitis $\mathrm{C}$ yang memiliki potensi lebih besar terkena hepatitis imbas obat (Devarbhavi, 2012). Berbeda dengan penelitian di RSUD Dr. Saeful Anwar Malang Rerata usia pasien kemoterapi anti-TB standar jangka pendek yang TB adalah 40,60 $\pm 18,267$ dengan 60\% berusia antara 25-50 (Rifai et al., 2015).

Dari jenis pekerjaan, 45 orang $(50,0 \%)$ yang bekerja, sebagian besar buruh sebanyak 42 orang $(46,7 \%)$. Dari 45 orang $(50,0 \%)$ tidak bekerja, terdapat 28 orang $(31,1 \%)$ tidak bekerja dan ibu rumah tangga 16 orang $(17,8 \%)$. Dari komposisi jenis pekerjaan dan status pekerjaan tidak terdapat perbedaan yang signifikan antara kelompok bekerja dan tidak bekerja. Tidak dapat digambarkan apakah status bekerja dan tidak bekerja tersebut dapat mendukung adanya faktor predisposisi TB dan hepatitis imbas obat dalam hal ini terkait faktor sosial seperti nutrisi

Berdasarkan domisili pasien, subjek penelitian paling banyak berdomisili di wilayah Kabupaten Bogor yaitu sebanyak 61 orang atau 67,8\%, sisanya dari berbagai kota atau kabupaten lain. Domisili pasien cukup bervariasi karena RSP dr. M. Goenawan Partowidigdo merupakan rumah sakit vertikal pemerintah rujukan kelas A untuk pelayanan penyakit paru. Data domisili selanjutnya akan digunakan sebagai dasar menentukan biaya kehilangan produktivitas dan biaya transport

Berdasarkan fase terapi tuberkulosis, fase pengobatan intensif merupakan fase pengobatan terbanyak yaitu sekitar 83 orang $(92,2 \%)$ dan pasien yang menjalani fase pengobatan lanjutan sebanyak 7 orang $(7,8 \%)$. Fase intensif merupakan fase 2 bulan pertama terapi OAT, dimana regimen yang diberikan adalah rifampisin, isoniazid, ethambutol, pyrazinamide untuk kategori I dan ditambah streptomisin pada kategori II. Hasil penelitian ini sejalan dengan penelitian yang dilakukan oleh (Savita Mishra, 2014), yang menyebutkan bahwa OAT seperti rifampisin, isoniazid dan pirazinamid yang digunakan dalam terapi TB secara signifikan dapat menyebabkan hepatotoksik pada mamalia dan dalam jangka waktu panjang dapat menyebabkan DILI (Drug Induced Liver Injury (Devarbhavi, 2012). Pyrazinamide merupakan regimen 
paling hepatotoksik, lalu diikuti oleh isoniazid dan rifampisin (Anand \& Hospitals, 2015). Berdasarkan fase terapi tuberkulosis, fase pengobatan intensif merupakan fase pengobatan terbanyak Hal ini sejalan dengan hasil penelitian Vitarani dkk. (2010), yang menyebutkan penderita tuberkulosis dengan hepatitis imbas obat paling banyak berada pada stage 1 dalam kategori WHO (Rahayu, 2018).

Pada kategori keparahan berdasarkan peningkatan kadar ALT diperoleh tingkat keparahan penyakit ringan sebanyak 69 orang (76,7\%), sedangkan tingkat keparahan penyakit sedang sebanyak 21 orang $(23,3 \%)$. Perbedaan tingkat keparahan yang dialami penderita dapat dipengaruhi beberapa faktor risiko, yaitu konsumsi alkohol (Abera et al, 2015), genetik, nilai serum ALT awal yang meningkat (Luthariana et al., 2017), jenis kelamin, malnutrisi dan penggunaan obat-obatan penginduksi hati David et al, 2010 dalam (Sintya, 2018). Usia lanjut, jenis kelamin, faktor gaya hidup, obesitas, status gizi, latar belakang genetik, dosis, dan durasi obat dapat memengaruhi risiko reaksi hepatotoksik karena obat. Dalam penelitian ini tidak diteliti faktor risiko yang dapat mempengaruhi keparahan kejadian hepatitis imbas obat. Dengan demikian dapat terjadi ketidakseragaman faktor risiko

\section{b. Efektivitas Hepatoprotektor}

Subjek penelitian diberikan hepatoprotektor secara acak meliputi kurkumin, lesitin dan plasebo/tanpa obat sebagaimana disajikan pada tabel 1 . Kriteria terkendali jika kadar ALT mencapai nilai normal <51 IU/L dan tidak terkendali jika kadar ALT tidak mencapai nilai normal (>51 IU/L).

Tabel 1 Distribusi frekuensi subjek penelitian berdasarkan efektivitasnya

\begin{tabular}{lcccccc}
\hline \multirow{2}{*}{$\begin{array}{l}\text { Jenis } \\
\text { Hepatoprotektor }\end{array}$} & \multicolumn{4}{c}{ Efektivitas } & \multirow{2}{*}{ Total } \\
\cline { 2 - 5 } & \multicolumn{2}{c}{ Terkendali } & \multicolumn{2}{c}{ Tidak Terkendali } & & \\
\hline Plasebo & $\mathrm{N}$ & $\%$ & $\mathrm{~N}$ & $\%$ & $\mathrm{~N}$ & $\%$ \\
\hline Kurkumin & 11 & $36,70 \%$ & 19 & $63,30 \%$ & 30 & $100 \%$ \\
\hline Lesitin & 8 & $26,70 \%$ & 22 & $73,30 \%$ & 30 & $100 \%$ \\
\hline Jumlah & 2 & $6,70 \%$ & 28 & $93,30 \%$ & 30 & $100 \%$ \\
\hline
\end{tabular}

Berdasarkan tabel diatas, sebanyak 21 orang $(23,33 \%)$ hasil pengobatannya terkendali, dan sebanyak 69 orang $(76,67 \%)$ hasil pengobatannya tidak terkendali.. Kriteria efektivitas berupa terkendali atau tidak terkendali, ditentukan berdasarkan hasil objektif pengukuran kadar ALT subjek pada hari ke-5 (lima). Penetapan hari ke-5 (lima) evaluasi kadar ALT merupakan asumsi dan didukung oleh hasil studi retrospektif terhadap kasus TB dengan hepatitis imbas obat yang terjadi di Rumah Sakit ini. Penanda lain berupa perbaikan gejala klinis hepatitis imbas obat dengan evaluasi atas 
keluhan pada akhir pengobatan tidak dijadikan dasar menetapkan efektivitas karena bersifat subjektif dan adanya keterbatasan data. Pada penelitian ini, yang dijadikan acuan hanyalah nilai ALT (alanin transaminase) karena peningkatan ALT merupakan penanda yang lebih spesifik pada gangguan hati dibandingkan dengan AST (aspartat aminotransferase). (Loho \& Hasan, 2014). Keduanya merupakan parameter yang mudah dilakukan di rumah sakit untuk menilai fungsi hati. Reny Setiowati dan Dumilah Ayuningtyas dalam penelitiannya mengatakan bahwa efek samping obat merupakan kendala besar yang harus dihadapi oleh pasien TB. Berbagai upaya dilakukan untuk menghindari efek samping obat ini salah satunya dengan pemberian tablet antasida untuk mengatasi mual pada lambung. Namun kebanyakan dari pasien TB tidak dapat mengatasi masalah ini, sebanyak $52,4 \%$ pasien TB mengeluhkan adanya efek samping obat (Reny Setiowati, 2017).

Dalam penelitian ini tidak diteliti faktor risiko yang dapat mempengaruhi keparahan kejadian hepatitis imbas obat, dengan demikian dapat terjadi ketidakseragaman faktor risiko. Kriteria efektivitas ditentukan berdasarkan hasil objektif pengukuran kadar ALT subjek pada hari ke-5 (lima). Penetapan hari ke-5 (lima) evaluasi kadar ALT merupakan asumsi dan didukung oleh hasil studi retrospektif terhadap kasus TB dengan hepatitis imbas obat yang terjadi di Rumah Sakit. Penelitian di Jepang tentang efektivitas hepatoprotektor menunjukkan bahwa tidak ada perbedaan signifikan pada penurunan nilai AST (Aspartate Transaminase)/ALT (Alanine Transminase) pada pasien yang mendapatkan hepatoprotektor dibandingkan dengan yang tidak mendapatkan hepatoprotektor (Saito et al., 2016).

\section{Distribusi Subjek Penelitian Berdasarkan Nilai ALT dan Biaya}

Berdasarkan penyajian pada tabel 2 diperoleh data nilai ALT awal ratarata 156,63IU/L dan standar deviasi 113,7 IU/L. Rata-rata nilai ALT akhir pengobatan 128,81 IU/L serta standar deviasi 105,8 IU/L. Rata-rata penurunan kadar ALT 27,82 IU/L. Namun nilai terendah adalah -348 IU/L dan tertinggi 213 IU/L dengan standar deviasi 85,5 IU/L Pada penelitian ini, yang dijadikan acuan hanyalah nilai ALT (alanin transaminase) karena peningkatan ALT merupakan penanda yang lebih spesifik pada gangguan hati dibandingkan dengan AST (aspartat aminotransferase).(Loho \& Hasan, 2014).

Biaya yang dikeluarkan untuk gejala klinik rata-rata Rp 306.511,00 dan standar deviasi Rp 106.117,00. Rata - rata biaya obat hepatoprotektor Rp 34.765,00 dengan standar deviasi $\mathrm{Rp}$ 47.662,00. Biaya rawat rata-rata $\mathrm{Rp}$ 398.611,00 dan standar deviasi $\mathrm{Rp} 317.388,00$. Biaya visit dokter rata-rata $\mathrm{Rp}$ 197.777,00 dan standar deviasi Rp 45.844,00. Biaya kamar untuk kelas utama adalah Rp 350.000,00, kelas 1 Rp 225.000,00, kelas 2 Rp 75.000,00 dan kelas 3 sebesar Rp 50.000,00. Biaya visite dokter juga berbeda untuk tiap kelas, yaitu kelas utama Rp 80.000,00, kelas 1 Rp60.000,00, kelas 2 Rp 40.000,00 dan 
kelas 3 sebesar Rp 35.000,00. Rata-rata biaya laboratorium Rp 49.255,00 dengan standar deviasi $\mathrm{Rp} 7.947,00 . \mathrm{Rp} 429.166,00$ dengan rata-rata peringkat 50,83 .

Tabel 2 Deskripsi Subjek Penelitian Berdasarkan Nilai ALT dan Biaya secara Keseluruhan

\begin{tabular}{lcccc}
\hline \multicolumn{1}{c}{ Variabel } & Minimum & Maksimum & Rata-rata & St.Dev \\
\hline Nilai Awal ALT & 52 & 487 & 156,63 & 113,7 \\
\hline Nilai Akhir ALT & 11 & 483 & 128,81 & 105,8 \\
\hline Penurunan ALT & -348 & 213 & 27,82 & 85,5 \\
\hline $\begin{array}{l}\text { Biaya Obat dan Alkes Gejala } \\
\text { Klinis }\end{array}$ & 131.552 & 629.690 & 306.511 & 106.117 \\
\hline Biaya Obat Hepatoprotektor & 0 & 103.400 & 34.765 & 47.622 \\
\hline Biaya Ruang Rawat & 250.000 & 1.750 .000 & 398.611 & 317.388 \\
\hline Biaya Visite Dokter & 175.000 & 400.000 & 197.777 & 45.844 \\
\hline Biaya Laboratorium & 44.000 & 66.000 & 49.255 & 7.947 \\
\hline Total Biaya Langsung & 600.552 & 2.612 .378 & 986.921 & 392.969 \\
\hline Biaya Transport & 22.000 & 780.000 & 280.511 & 151.995 \\
\hline $\begin{array}{l}\text { Biaya Kehilangan } \\
\text { Produktivitas }\end{array}$ & 0 & 768.274 & 317.943 & 344.796 \\
\hline Total Biaya Tidak Langsung & $\mathbf{2 2 . 0 0 0}$ & 1.288 .733 & 598.454 & 371.556 \\
\hline Total Biaya & $\mathbf{7 8 9 . 2 1 0}$ & $\mathbf{3 . 2 7 8 . 3 7 8}$ & $\mathbf{1 . 5 8 5 . 3 7 5}$ & $\mathbf{5 6 3 . 8 9 7}$ \\
\hline
\end{tabular}

Total biaya langsung medik yang dikeluarkan subjek penelitian rata-rata Rp 986.921,00 dan standar deviasi Rp 329.969,00. Biaya transportasi yang dikeluarkan oleh subjek penelitian rata-rata $\mathrm{Rp} 280.511,00$ serta standar deviasi Rp 151.995,00. Biaya kehilangan produktivitas akibat sakit rata-rata Rp 317.943,00 dan standar deviasi Rp 344.796.,00. Total biaya tidak langsung yang dikeluarkan subjek penelitian rata-rata $\mathrm{Rp} 598.454,00$ dan standar deviasi Rp 371.556,00. Perhitungan biaya tidak langsung dalam penelitian ini, tidak melibatkan biaya akomodasi dan biaya kehilangan produktivitas pendamping karena tidak diperoleh data yang akurat. Dari total biaya langsung dan biaya tidak langsung di atas, maka total biaya yang dikeluarkan oleh subjek penelitian paling rendah sebesar $\mathrm{Rp} 789.210,00$ dan yang tertinggi $\mathrm{Rp}$ 3.278.378,00 dengan rata-rata $\mathrm{Rp} 1.585 .375,00$ dan standar deviasi $\mathrm{Rp}$ $563.897,00$.

Biaya laboratorium dihitung berdasarkan tarif pemeriksaan fungsi hati yaitu ALT dan AST. Tarif pemeriksaan tersebut bervariasi sesuai kelas rawat, yaitu kelas utama dan kelas 1 sebesar Rp 33.000,00, kelas 2 sebesar Rp 27.500,00 dan kelas 3 sebesar Rp 22.000,00. Evaluasi laboratorium atas nilai ALT dilakukan setelah 5 hari, berdasarkan hasil studi retropektif di rumah sakit ini terkait penanganan pasien tuberkulosis dengan hepatitis imbas obat (Syntia,2018). Semua biaya dihitung dengan asumsi 5 (lima hari) dan didukung hasil studi retrospektif yang dilakukan di rumah sakit ini oleh 
(Sintya, 2018), bahwa rentang waktu rawat untuk pasien tuberkulosis dengan hepatitis imbas obat adalah 3-5 hari Biaya untuk gejala klinik meliputi obatobatan dan alat medis habis pakai.

\section{Analisis Bivariat}

Kemudian untuk mengetahui hubungan antar variabel dilakukan analisis bivariat dengan Uji beda Mann Whitney, Uji Kruskal Wallis dan Uji Chi square.

a. Uji Beda Mann Whitney

Hasil uji beda Mann Whitney disajikan pada tabel 3. Uji antara kelompok plasebo dan kelompok kurkumin diperoleh nilai akhir ALT dengan $\mathrm{p}=0,120$ $>0,05$, dan total biaya langsung dengan $p=0,274>0,05$. Kesimpulannya tidak ada perbedaan bermakna penggunaan plasebo dan kurkumin. Akan tetapi .penggunaan plasebo dan kurkumin berbeda bermakna pada biaya hepatoprotektor dengan $\mathrm{p}=0,000<0,05$. Hasil uji beda Mann Whitney antara kelompok plasebo dan kelompok lesitin menunjukkan perbedaan nilai akhir ALT dengan $\mathrm{p}=0,005<0,05$, biaya hepatoprotektor dengan $\mathrm{p}=0,000<$ 0,005 , dan total biaya langsung dengan $\mathrm{p}=0,010<0,05$. Kesimpulannya ada perbedaan bermakna penggunaan plasebo dan lesitin. Hasil uji beda Mann Whitney antara kelompok kurkumin dan kelompok lesitin menunjukkan perbedaan nilai ALT 2 dengan $\mathrm{p}=0,203>0,05$, biaya dan total biaya langsung dengan $\mathrm{p}=0,274>0,05$. Kesimpulannya tidak ada perbedaan bermakna penggunaan plasebo dan kurkumin. Akan tetapi .penggunaan plasebo dan kurkumin berbeda bermakna pada biaya hepatoprotektor dengan $\mathrm{p}$ $=0,000<0,05$.

b. Uji Kruskal Wallis

Hasil uji Kruskal Wallis disajikan pada tabel 4. Rata-rata penurunan kadar ALT subjek penelitian yang menggunakan plasebo 34,93 IU/L dengan rata-rata peringkat 45,43. yang menggunakan hepatoprotektor kurkumin, ratarata penurunan kadar ALT 17,63 IU/L dengan rata-rata peringkat 42,10. Sedangkan yang menggunakan hepatoprotektor lesitin rata-rata penurunan kadar ALT 30,77 IU/L dengan rata-rata peringkat 48,97. Hasil uji statistik diperoleh nilai $\mathrm{X}^{2}=1,037$ dan $\mathrm{p}$ value $=0,595$. Dari hasil ini dapat disimpulkan bahwa pada taraf alpha 5\% tidak terdapat hubungan yang bermakna rata-rata penurunan kadar ALT pada ketiga kelompok subjek penelitian. Rata-rata biaya obat dan alkes untuk mengatasi gejala klinis yang dikeluarkan subjek penelitian yang menggunakan plasebo adalah $\mathrm{Rp}$ 307.958,00 dengan rata-rata peringkat 44,30. Pada subjek penelitian yang menggunakan hepatoprotektor kurkumin, biaya obat dan alkes untuk mengatasi gejala klinis yang dikeluarkannya adalah $\mathrm{Rp} 323.848,00$ dengan rata-rata peringkat 51,21. Sedangkan subjek yang menggunakan hepatoprotektor lesitin rata-rata biaya klinis yang dikeluarkannya adalah $\mathrm{Rp} 287.728,00$ dengan ratarata peringkat 41,00 . 
Hasil uji statistik diperoleh nilai $X^{2}=2,382$ dengan $\mathrm{p}$ value $=0,304$, dengan demikian dapat disimpulkan bahwa pada taraf alpha 5\% tidak terdapat perbedaan yang bermakna rata-rata biaya klinis yang dikeluarkan pada ketiga kelompok subjek penelitian tersebut. Rata-rata biaya obat hepatoprotektor yang dikeluarkan subjek penelitian yang menggunakan plasebo adalah Rp0 dengan rata-rata peringkat 15,50 .

Pada subjek yang menggunakan hepatoprotektor kurkumin, rata-rata biaya obat hepatoprotektor yang dikeluarkannya adalah $\mathrm{Rp} 4.343,00$ dengan rata-rata peringkat 45,50. Sedangkan subjek yang menggunakan hepatoprotektor lesitin rata-rata biaya yang dikeluarkannya adalah Rp103.400,00 dengan rata-rata peringkat 75,50. Hasil uji statistik diperoleh nilai $X^{2}=89,000$ dengan $p$ value $=0,000$, dengan demikian dapat disimpulkan bahwa pada taraf alpha $5 \%$ terdapat perbedaan yang bermakna rata-rata peringkat biaya obat hepatoprotektor yang dikeluarkan pada ketiga kelompok subjek penelitian tersebut. Rata-rata biaya ruang rawat yang dikeluarkan oleh subjek peenelitian yang menggunakan plasebo adalah Rp 400.000,00 dengan rata-rata peringkat 40,72 .

Tabel 3 Hasil Uji Beda Mann Whitney

\begin{tabular}{|c|c|c|c|}
\hline Variabel & $\begin{array}{c}\text { Kelompok } \\
\text { Hepatoprotektor }\end{array}$ & p-Value & Kesimpulan \\
\hline \multirow[t]{6}{*}{ Nilai Akhir ALT } & Plasebo & 0,120 & berbeda \\
\hline & Kurkumin & 0,05 & bermakna \\
\hline & Plasebo & 0,005 & berbeda bermakna \\
\hline & Lesitin & 0,05 & \\
\hline & Kurkumin & 0,203 & berbeda \\
\hline & Lesitin & 0,05 & bermakna \\
\hline \multirow{6}{*}{$\begin{array}{l}\text { Biaya } \\
\text { Hepatoprotektor }\end{array}$} & Plasebo & 0,000 & berbeda bermakna \\
\hline & Kurkumin & 0,05 & \\
\hline & Plasebo & 0,000 & berbeda bermakna \\
\hline & Lesitin & 0,05 & \\
\hline & Kurkumin & 0,000 & berbeda bermakna \\
\hline & Lesitin & 0,05 & \\
\hline \multirow{6}{*}{$\begin{array}{ll}\text { Total } & \text { Biaya } \\
\text { Langsung } & \end{array}$} & Plasebo & 0,274 & berbeda \\
\hline & Kurkumin & 0,05 & bermakna \\
\hline & Plasebo & 0,010 & berbeda bermakna \\
\hline & Lesitin & 0,05 & \\
\hline & Kurkumin & 0,027 & berbeda bermakna \\
\hline & Lesitin & 0,05 & \\
\hline
\end{tabular}

Pada subjek yang menggunakan hepatoprotektor kurkumin, biaya ruang rawat yang dikeluarkan adalah $\mathrm{Rp} 366.666,00$ dengan rata-rata peringkat 47,95. Pada subjek yang menggunakan hepatoprotektor lesitin rata-rata biaya ruang rawat yang dikeluarkannya adalah $\mathrm{Rp} 429.166,00$ dengan rata-rata peringkat 50,83. Hasil uji statistik diperoleh nilai $X^{2}=3,270$ dengan $p$ value $=$ 0,195 , dengan demikian dapat disimpulkan bahwa pada taraf alpha $5 \%$ tidak 
terdapat perbedaan yang bermakna rata-rata peringkat biaya ruang rawat yang dikeluarkan pada ketiga kelompok subjek penelitian tersebut. Rata - rata biaya visit dokter yang dikeluarkan subjek penelitian yang menggunakan plasebo adalah Rp 196.666,00 dengan rata-rata peringkat 40,72

Pada subjek penelitian yang menggunakan hepatoprotektor kurkumin, biaya visit dokter yang dikeluarkannya adalah $\mathrm{Rp}$ 193.333,00 dengan rata-rata peringkat 47,95. Sedangkan subjek penelitian yang menggunakan hepatoprotektor lesitin rata-rata biaya visit dokter yang dikeluarkannya adalah Rp 203.333,00 dengan rata-rata peringkat 50,83. Hasil uji statistik diperoleh nilai $X^{2}=3,270$ dengan $p$ value $=0,195$, dengan demikian dapat disimpulkan bahwa pada taraf alpha 5\% tidak terdapat perbedaan yang bermakna rata-rata peringkat biaya visit dokter yang dikeluarkan pada ketiga kelompok subjek penelitian tersebut. Rata-rata biaya laboratorium yang dikeluarkan subjek penelitian yang menggunakan plasebo adalah Rp 48.400,00 dengan rata-rata peringkat 41.68. Pada subjek penelitian yang menggunakan hepatoprotektor kurkumin, biaya laboratorium yang dikeluarkannya adalah $\operatorname{Rp} 48.766,00$ dengan rata-rata peringkat 44.55. Sedangkan subjek penelitian yang menggunakan hepatoprotektor lesitin rata-rata biaya laboratorium yang dikeluarkannya adalah Rp 50.600,00 dengan rata-rata peringkat 50.27. Hasil uji statistik diperoleh nilai $\mathrm{X}^{2}=2,376$ dengan $\mathrm{p}$ value $=0,305$, dengan demikian dapat disimpulkan bahwa pada taraf alpha 5\% tidak terdapat perbedaan yang bermakna rata-rata peringkat biaya laboratorium yang dikeluarkan pada ketiga kelompok subjek penelitian tersebut.

Rata-rata biaya langsung yang dikeluarkan subjek penelitian yang menggunakan plasebo adalah $\mathrm{Rp}$ 953.025,00 dengan rata-rata peringkat 35,53. Pada subjek penelitian yang menggunakan hepatoprotektor kurkumin, biaya langsung yang dikeluarkannya adalah $\mathrm{Rp}$ 976.046,00 dengan rata-rata peringkat 46,03. Sedangkan subjek penelitian yang menggunakan hepatoprotektor lesitin rata-rata biaya langsung yang dikeluarkannya adalah Rp1.074.228,00 dengan rata-rata peringkat 54,93. Hasil uji statistik diperoleh nilai $\mathrm{X}^{2}=8,290$ dengan $\mathrm{p}$ value $=0,016$, dengan demikian dapat disimpulkan bahwa pada taraf alpha 5\% terdapat perbedaan yang bermakna rata-rata peringkat biaya langsung yang dikeluarkan pada ketiga kelompok subjek penelitian tersebut. Rata-rata biaya transport yang dikeluarkan subjek penelitian yang menggunakan plasebo adalah $\mathrm{Rp} 244.333,00$ dengan rata-rata peringkat 39,47. Pada subjek penelitian yang menggunakan hepatoprotektor kurkumin, biaya transport yang dikeluarkannya adalah $\mathrm{Rp} 289.533,00$ rata-rata peringkat47,47.Sedangkan subjek penelitian yang menggunakan hepatoprotektor lesitin rata-rata biaya transport yang dikeluarkannya adalah $\mathrm{Rp}$ 307.666,00 dengan rata-rata peringkat 49,57. Hasil uji statistik diperoleh nilai $X^{2}=2,498$ dengan $p$ value $=0,287$, dengan demikian dapat disimpulkan bahwa pada taraf alpha 5\% tidak terdapat perbedaan yang bermakna rata-rata biaya transport yang dikeluarkan pada ketiga kelompok subjek penelitian tersebut. Rata-rata kehilangan produktivitas subjek penelitian yang menggunakan plasebo adalah $\mathrm{Rp} 313.337,00$ dengan rata-rata peringkat 44,65.

Pada subjek penelitian yang menggunakan hepatoprotektor kurkumin, biaya kehilangan produktivitas adalah $\mathrm{Rp} 259.323,00$ dengan rata-rata peringkat 42,82. Sedangkan subjek penelitian yang menggunakan 
hepatoprotektor lesitin rata-rata biaya kehilangan produktivitas adalah $\mathrm{Rp}$ 381.169,00 dengan rata-rata peringkat 49,03. Hasil uji statistik diperoleh nilai $\mathrm{X}^{2}=1,106$ dengan $\mathrm{p}$ value $=0,575$, dengan demikian dapat disimpulkan bahwa pada taraf alpha 5\% tidak terdapat perbedaan yang bermakna rata-rata kerugian produktivitas pada ketiga kelompok subjek penelitian tersebut. Rata-rata biaya tidak langsung yang dikeluarkan subjek penelitian yang menggunakan plasebo adalah Rp 557.670,00 dengan rata-rata peringkat 41,92.

Tabel 4 Hasil Uji Kruskal Wallis

\begin{tabular}{|c|c|c|c|c|c|}
\hline Hepatoprotektor & $\mathrm{N}$ & Mean & $\begin{array}{l}\text { Mean } \\
\text { Rank }\end{array}$ & $\mathrm{X}^{2}$ & $\begin{array}{c}\mathrm{P} \\
\text { Value }\end{array}$ \\
\hline \multicolumn{6}{|l|}{ 1. Rata-rata penurunan ALT } \\
\hline Plasebo & 30 & 34.93 & 45.43 & \multirow[t]{3}{*}{1.037} & \multirow[t]{3}{*}{0,595} \\
\hline Kurkumin & 30 & 17.63 & 42.10 & & \\
\hline Lesitin & 30 & 30.77 & 48.97 & & \\
\hline \multicolumn{6}{|c|}{ 2. Rata-rata pengeluaran biaya obat dan alkes gejala klinis } \\
\hline Plasebo & 30 & 307958 & 44.30 & \multirow[t]{3}{*}{2.382} & \multirow[t]{3}{*}{0.304} \\
\hline Kurkumin & 30 & 323848 & 51.20 & & \\
\hline Lesitin & 30 & 287728 & 41.00 & & \\
\hline \multicolumn{6}{|c|}{ 3. Rata-rata pengeluaran biaya obat hepatoprotektor } \\
\hline Plasebo & 30 & 0 & 15.50 & \multirow[t]{3}{*}{$\begin{array}{c}89.00 \\
0\end{array}$} & \multirow[t]{3}{*}{0.000} \\
\hline Kurkumin & 30 & 4343 & 45.50 & & \\
\hline Lesitin & 30 & 103400 & 75.50 & & \\
\hline \multicolumn{6}{|l|}{ 4. Rata-rata pengeluaran biaya ruang rawat } \\
\hline Plasebo & 30 & 400000 & 40.72 & \multirow[t]{3}{*}{3.270} & \multirow[t]{3}{*}{0.195} \\
\hline Kurkumin & 30 & 366666 & 44.95 & & \\
\hline Lesitin & 30 & 429166 & 50.83 & & \\
\hline \multicolumn{6}{|l|}{ 5. Rata-rata pengeluaran biaya visite dokter } \\
\hline Plasebo & 30 & 48400 & 41.68 & \multirow[t]{3}{*}{2.376} & \multirow[t]{3}{*}{0.305} \\
\hline Kurkumin & 30 & 48766 & 44.55 & & \\
\hline Lesitin & 30 & 50600 & 50.27 & & \\
\hline \multicolumn{6}{|l|}{ 6. Rata-rata pengeluaran biaya laboratorium } \\
\hline Plasebo & 30 & 196666 & 40.72 & \multirow[t]{3}{*}{3.270} & \multirow[t]{3}{*}{0.195} \\
\hline Kurkumin & 30 & 193333 & 44.95 & & \\
\hline Lesitin & 30 & 203333 & 50.83 & & \\
\hline \multicolumn{6}{|l|}{ 7. Rata-rata pengeluaran biaya langsung } \\
\hline Plasebo & 30 & 953025 & 35,53 & \multirow[t]{3}{*}{8,290} & \multirow[t]{3}{*}{0.016} \\
\hline Kurkumin & 30 & 976046 & 46,03 & & \\
\hline Lesitin & 30 & 1074228 & 54,93 & & \\
\hline \multicolumn{6}{|l|}{ 8. Rata-rata pengeluaran biaya transport } \\
\hline Plasebo & 30 & 244333 & 39.47 & \multirow[t]{3}{*}{2.498} & \multirow[t]{3}{*}{0.287} \\
\hline Kurkumin & 30 & 289533 & 47.47 & & \\
\hline Lesitin & 30 & 307666 & 49.57 & & \\
\hline 9. Rata-rata kehilangan produktivitas & & & & & \\
\hline Plasebo & 30 & 313337 & 44.65 & 1.106 & 0.575 \\
\hline Kurkumin & 30 & 259323 & 42.82 & & \\
\hline Lesitin & 30 & 381169 & 49.03 & & \\
\hline 10. Rata-rata pengeluaran total biaya tid & & & & & \\
\hline Plasebo & 30 & 557670 & 41.92 & 2.768 & 0.251 \\
\hline Kurkumin & 30 & 548856 & 42.62 & & \\
\hline Lesitin & 30 & 688836 & 51.97 & & \\
\hline 11. Rata-rata pengeluaran total biaya & & & & & \\
\hline Plasebo & 30 & 1510696 & 39,37 & 4,056 & 0,132 \\
\hline Kurkumin & 30 & 1524903 & 44,33 & & \\
\hline Lesitin & 30 & 1763064 & 52,80 & & \\
\hline
\end{tabular}


Pada subjek penelitian yang menggunakan hepatoprotektor kurkumin, biaya tidak langsung yang dikeluarkannya adalah Rp 548.856,00 dengan ratarata peringkat 42,62. Sedangkan subjek penelitian yang menggunakan hepatoprotektor lesitin rata-rata biaya tidak langsung yang dikeluarkannya adalah $\mathrm{Rp} 688.836,00$ dengan rata-rata peringkat 51,97. Hasil uji statistik diperoleh nilai $\mathrm{X}^{2}=2,768$ dengan $\mathrm{p}$ value $=0,251$, dengan demikian dapat disimpulkan bahwa pada taraf alpha $5 \%$ tidak terdapat perbedaan yang bermakna rata-rata biaya tidak langsung yang dikeluarkan pada ketiga kelompok subjek penelitian tersebut. Rata-rata total biaya yang dikeluarkan subjek penelitian yang menggunakan plasebo adalah Rp 1.510.696,00 dengan rata-rata peringkat 39,37. Pada subjek penelitian yang menggunakan hepatoprotektor kurkumin, total biaya yang dikeluarkan adalah $\mathrm{Rp}$ 1.524.903,00 dengan rata-rata peringkat 44,33. bat hepatoprotektor dan total biaya langsung

Sedangkan subjek penelitian yang menggunakan hepatoprotektor lesitin rata-rata total biaya yang dikeluarkannya adalah Rp 1.763.064,00 dengan ratarata peringkat 52,80, yang dikeluarkan pada ketiga kelompok subjek penelitian tersebut. Hal ini dikarenakan dari seluruh komponen biaya hanya ada perbedaan bermakna pada biaya o

c. Uji Chi square.

Hasil Uji Chi Square dapat dilihat pada tabel 5. Berdasarkan tingkat keparahan, pada keparahan ringan dari 69 subjek penelitian, terdapat 21 subjek penelitian atau 30,4\% yang terkendali hepatitis imbas obatnya dan $48(69,6 \%)$ subjek tidak terkendali. Pada tingkat keparahan sedang, dari 21 subjek penelitian, 21 subjek (100\%) tidak terkendali masalah hepatitis imbas obat yang dialaminya. Hasil uji statistik diperoleh $p$ value $=0,02$, dengan demikian dapat disimpulkan bahwa pada taraf alpha 5\% terdapat perbedaan yang bermakna antara tingkat keparahan dan efektivitas pengobatan.

Pada penelitian ini setiap sampel diperlakukan sama, dimana sampel dengan kadar ALT tinggi diukur dengan hasil atau luaran yang sama dengan sampel dengan kadar awal ALT yang rendah.Subjek penelitian diberikan obat hepatoprotektor atau plasebo sesuai hasil random yang dilakukan oleh petugas di Depo Farmasi IGD.

Berdasarkan efektivitas hepatoprotektor yang diberikan, diketahui bahwa ada sebanyak 11 orang subjek penelitian pada kelompok plasebo yang hasil pengobatannya terkendali 36,67\%, sedangkan sisanya sebanyak 19 subjek penelitian dengan hasil pengobatan yang tidak terkendali (63,33\%). Pada subjek penelitian pada kelompok kurkumin terdapat 8 orang yang hasil pengobatannya terkendali $(26,67 \%)$, sedangkan yang tidak terkendali sebanyak 22 atau sebesar 73,33\%. Sebanyak 2 orang subjek penelitian pada kelompok lesitin yang hasil pengobatannya terkendali $(6,67 \%)$, sedangkan 
sisanya sebanyak 28 subjek penelitian dengan hasil pengobatan yang tidak terkendali $(93,33 \%)$.

Tabel 5 Hasil Uji Chi Square

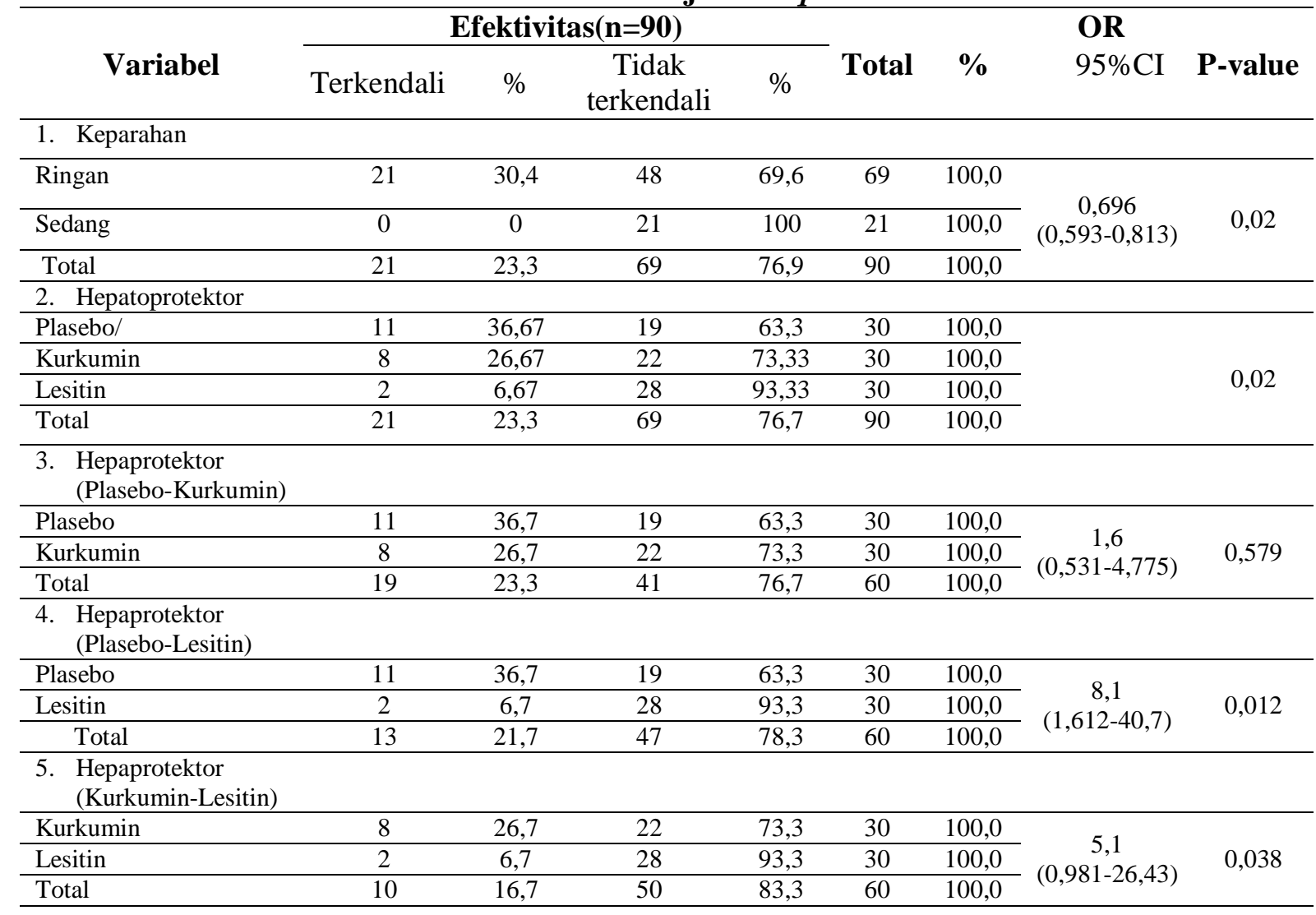

Berdasarkan hasil uji statistik yang dilakukan diperoleh $\mathrm{p}$ value sebesar 0,02. Dengan demikian dapat disimpulkan bahwa terdapat perbedaan yang signifikan hasil pengobatan hepatitis imbas obat pada ketiga kelompok tersebut. Dari 30 orang subjek penelitian yang menggunakan plasebo, ada 11 orang atau sebesar $36,7 \%$ yang efektivitas pengobatannya terkendali. Tiga puluh (30) orang subjek yang menggunakan kurkumin, ada 8 orang atau 26,7\% yang efektifvitas pengobatannya terkendali. Berdasarkan hasil uji statistik yang dilakukan diperoleh $\mathrm{p}$ value sebesar 0,579. Dengan demikian dapat disimpulkan bahwa pada pasien tuberkulosis dengan hepatitis imbas obat tidak terdapat perbedaan hasil pengobatan yang signifikan antara plasebo dan penggunaan kurkumin.

Dari sebanyak 30 orang subjek penelitian yang menggunakan plasebo, ada 11 orang atau sebesar $36,7 \%$ yang efektivitas pengobatannya terkendali. Tiga puluh (30) orang subjek yang menggunakan lesitin, ada 2 orang atau 6,7\% yang efektifitas pengobatannya terkendali. Berdasarkan hasil uji statistik yang dilakukan diperoleh $\mathrm{p}$ value sebesar 0,012. Dengan demikian dapat disimpulkan bahwa ada perbedaan efektifivitas pengobatan antara plasebo dan lesitin. Dilihat dari nilai OR maka subjek penelitian yang menggunakan 
plasebo efektivitas pengobatannya 8,1 kali lebih tinggi dibanding dengan subjek penelitian yang menggunakan lesitin. Dari 30 subjek penelitian yang menggunakan kurkumin, ada 8 orang atau sebesar $26,7 \%$ yang efektivitas pengobatannya terkendali. Tiga puluh (30) orang subjek yang menggunakan lesitin, ada 2 orang atau $6,7 \%$ yang efektivitas pengobatannya terkendali.

Penderita tuberkulosis dengan hepatitis imbas obat memiliki keluhan klinis yang hampir sama ketika masuk rumah sakit. Keluhan tersebut sakit perut, nausea, muntah, unexplained fatigue, atau jaundice atau meningkat lima kali lipat dari ULN tanpa disertai gejala (Ramappa \& Aithal, 2013). Hasil penelitian ini berbeda dengan penelitian (Liu et al., 2016), yang menyatakan tidak ada perbedaan pengaruh tingkat keparahan terhadap normalisasi enzim hepatik (Liu et al., 2016). Pemilihan kurkumin dan lesitin didasarkan pada hasil studi retrospektif yang dilakukan di rumah sakit ini oleh (Sintya, 2018), dimana jenis hepatoprotektor yang paling sering digunakan adalah kurkumin (Curcuma $^{\mathrm{R}}$ ), kurkumin-silymarin (Hepa $\mathrm{Q}^{\mathrm{R}}$ ) dan lesitin $\left(\right.$ Lesichol $^{\mathrm{R}}$ ). (Saukkonen J J, Cohn D L, Jasmer R M, Schenker S, Jereb J A, Nolan C M, et al., 2006). Penggunaan plasebo menunjukkan efektiviitas paling besar, hal ini selaras dengan Pedoman Nasional Pelayanan Kedokteran Ttalaksana Tuberkulosis yang menyatakan bahwa hepatitis imbas obat dapat pulih tanpa obat dan hanya dengan penghentian pemberian obat penyebab ((Kemenkes RI), 2013). Menurut (Singh, Jodave, Bhatt, Gill, \& Suresh, 2014) kurkumin diyakini mempunyai efek kemoprotektif, antioksidan dan antiinflamasi (Savita Mishra, 2014).

Berdasarkan hasil uji statistik yang dilakukan diperoleh $\mathrm{p}$ value sebesar 0,038. Dengan demikian dapat disimpulkan bahwa penggunaan hepatoprotektor kurkumin dan lesitin memberikan hasil dengan perbedaan yang signifikan. Apabila dilihat dari nilai OR, maka dikatakan bahwa pengobatan dengan kurkumin 5,1 kali lebih efektif dibanding dengan lesitin. Dilihat dari nilai OR, subjek penelitian yang menggunakan plasebo efektivitas pengobatannya 8,1 kali lebih tinggi dibanding dengan yang menggunakan lesitin. Hal ini selaras dengan Pedoman Nasional Pelayanan Kedokteran Tatalaksana Teberkulosis dan Pedoman Diagnosis dan Penatalaksanaan Tuberkulosis Persatuan Dokter Paru Indonesia, bahwa hepatitis imbas obat akan terkendali dengan menghentikan obat yang bersifat hepatotoksik ((Kemenkes RI), 2013). Sebuah penelitian oleh (Singh et al., 2014) pada pengobatan dengan isoniazid dan penambahan kurkumin, terjadi pengurangan toksisitas yang cukup besar, ditunjukkan oleh perubahan kadar kolesterol, albumin dan peroksidasi lipid. Hal tersebut dikaitkan dengan aktivitas antioksidan dari kurkumin (Singh et al., 2014). 


\section{Analisis Farmakoekonomi}

Perhitungan Unit Cost/Average Cost Effectiveness Ratio Penggunaan Hepatoprotektor pada Penderita Tuberkulosis dengan Hepatitis Imbas Obat

Untuk mengetahui perbandingan biaya mana yang lebih cost effective antara penggunaan plasebo, kurkumin atau lesitin dilakukan perhitungan unit cost / ACER. Hasilnya disajikan pada tabel 6 dan tabel 7. Dari tabel tersebut dapat dilihat bahwa, unit cost untuk mengatasi hepatitis imbas obat dengan menggunakan plasebo/tanpa obat adalah paling rendah yaitu $\mathrm{Rp} 4.120 .342$, 23. Selanjutnya unit cost untuk penggunaan kurkumin adalah $\mathrm{Rp} 5.571 .803,76$ dan paling tinggi adalah unit cost untuk penggunaan lesitin sebesar Rp 26.444.523,64. Selanjutnya dibandingkan cost effectiveness ratio masing-masing obat hepatoprotektor dan plasebo. Hasil perbandingan nilai CER menunjukkan bahwa bahwa CER terendah adalah CER plasebo terhadap kurkumin yaitu 0,16, lalu CER kurkumin terhadap lesitin dan tertinggi adalah CER plasebo terhadap kurkumin. Dengan demikian penggunaan plasebo lebih cost effectives dibandingkan dengan obat hepatoprotektor yang lain. Pilihan berikutnya yang cukup cost effective adalah kurkumin.

Tabel 6 Hasil Unit Cost/Average Cost Effectiveness Ratio

\begin{tabular}{|c|c|c|c|}
\hline & Plasebo & Kurkumin & Lesitin \\
\hline Total Biaya Langsung & Rp28.425.653,54 & Rp28.108.738,13 & Rp32.391.965,28 \\
\hline $\begin{array}{l}\text { Total Biaya Tidak } \\
\text { Langsung }\end{array}$ & Rp16.898.111,00 & Rp16.465.692,00 & Rp20.497.082,00 \\
\hline Total Biaya/Total Cost & Rp45.323.764,54 & Rp44.574.430,13 & Rp52.889.047,28 \\
\hline Efektivitas & 11 & 8 & 2 \\
\hline $\begin{array}{l}\text { Unit Cost / } \\
\text { ACER } \quad\left(=\frac{\text { Biaya }}{\text { Efektivitas }}\right)\end{array}$ & Rp4.120.342,23 & Rp5.571.803,76 & Rp26.444.523,64 \\
\hline
\end{tabular}

Tabel 7 Hasil Perbandingan Cost Efectiveness Ratio/CER

\begin{tabular}{lcccc}
\hline \multirow{2}{*}{ JENIS OBAT } & ACER & \multicolumn{3}{c}{ CER } \\
& & \multicolumn{2}{c}{ (Cost Effectiveness Analysis) } \\
\cline { 3 - 5 } & (rupiah/efektivitas) & Plasebo/Kurkumin & $\begin{array}{l}\text { Plasebo } \\
\text { /Lesitin }\end{array}$ & $\begin{array}{l}\text { Kurkumi } \\
\text { n/lesitin }\end{array}$ \\
\hline Plasebo & $4.120 .342,23$ & $\mathbf{0 , 7 4}$ & & \\
\hline Kurkumin & $5.571 .803,76$ & & $\mathbf{0 , 1 6}$ & \\
\hline Lesitin & $26.444 .523,64$ & & $\mathbf{0 , 2 1}$ \\
\hline
\end{tabular}

\section{Uji Sensitivitas Penggunaan Hepatoprotektor pada Penderita Tuberkulosis dengan Hepatitis Imbas Obat}

Dalam penelitian ini dilakukan pula uji sensitivitas penggunaan Hepatoprotektor pada Penderita Tuberkulosis dengan Hepatitis Imbas Obat dengan menghitung perubahan nilai variabel biaya total menggunakan kisaran nilai 0\%, 5\% dan $10 \%$ sedangkan variabel lainnya yaitu efektivitas diperlakukan tetap. 


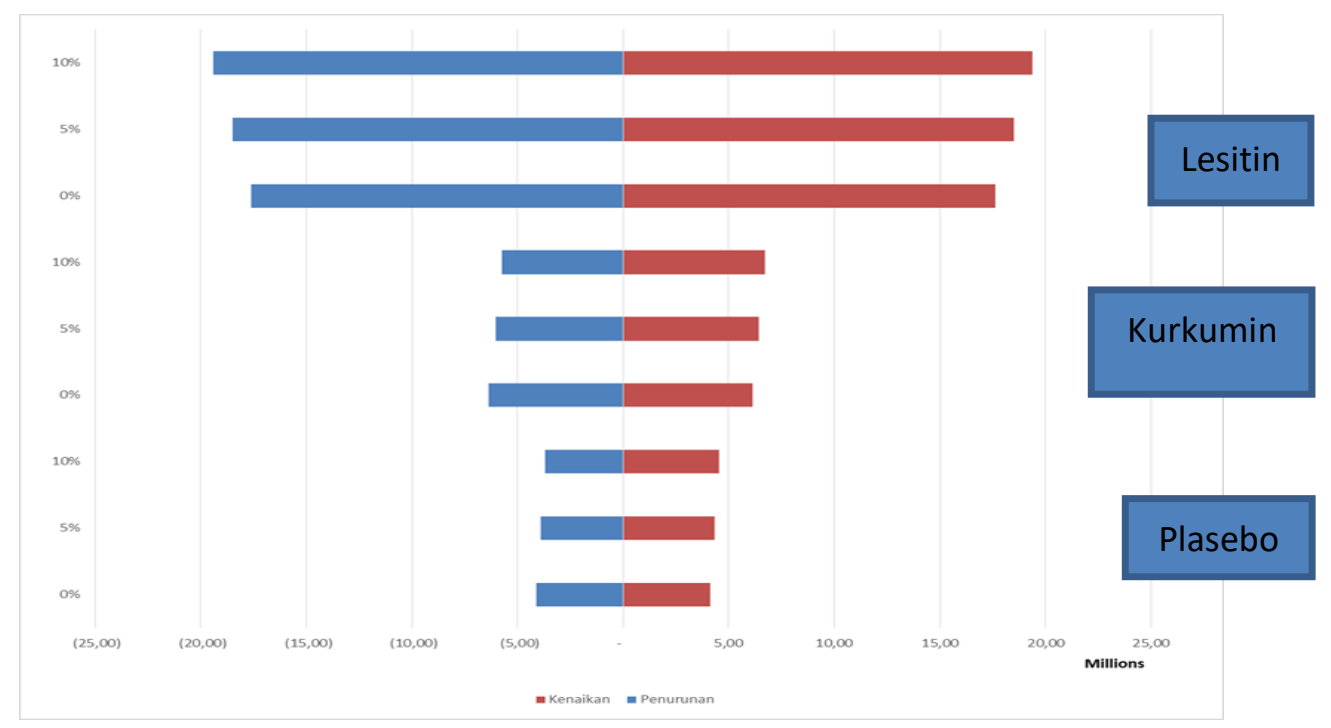

Gambar 1 Diagram Tornado

Pada Gambar 1 berikut dihitung perubahan nilai variabel biaya total menggunakan kisaran nilai $0 \%, 5 \%$ dan $10 \%$ sedangkan variabel lainnya yaitu efektivitas diperlakukan tetap.

Analisis sensitivitas perlu dilakukan untuk menganalisis parameter yaitu estimasi biaya, efektivitas dan efektivitas-biaya yang diperoleh dari hasil studi evaluasi ekonom karena memiliki ketidakpastian (uncertainty) akibat berbagai sebab. Ketidakpastian tersebut misalnya karena keterbatasan data atau keterbatasan analisis oleh karena menggunakan nilai rerata (mean) padahal realitasnya data tidak terdistribusi secara normal (Singh et al., 2014). Diagram Tornado digunakan untuk melihat ketidakpastian atau dampak perubahan parameter terhadap luaran yang terjadi.

Pengendalian TB yang menjadi rekomendasi WHO adalah penerapan strategi pengobatan jangka pendek dengan pengawasan langsung atau Directly Observed Treatment Shortcourse (DOTS). Strategi DOTS mempunyai lima buah komponen kunci, yaitu komitmen politis dengan peningkatan dan kesinambungan pendanaan; penemuan kasus dengan melalui pemeriksaan dahak mikroskopis yang terjamin mutunya; pengobatan yang standar dengan supervisi dan dukungan bagi pasien penderita; sistem pengelolaan dan ketersediaan obat anti-tuberkulosis (OAT) yang efektif; dan sistem monitoring, pencatatan dan pelaporan yang mampu memberikan penilaian terhadap hasil pengobatan pasien dan kinerja program (Pratiwi, Rohmawaty, \& Kulsum, 2018).

\section{Kesimpulan}

Tanpa menggunakan hepatoprotektor, kejadian hepatitis imbas obat akibat penggunaan obat anti tuberkulosis dapat membaik. Efektivitas hepatoprotektor dalam pengobatan pasien tuberkulosis dengan hepatitis imbas obat paling tinggi untuk menurunkan kadar ALT sampai nilai normal (<51U/L) adalah kurkumin. Nilai unit 
cost atau ACER (An Average Cost Effective) berdasarkan efektivitas hepatoprotektor, paling rendah adalah pada penggunaan plasebo yaitu Rp4.120.342, 23, sedangkan pada penggunaan kurkumin sebesar Rp 5.571.803,76 dan pada penggunaan lesitin Rp 25.444.523,64. 


\section{BIBLIOGRAFI}

(Kemenkes RI), Kementerian Kesehatan Republik Indonesia. (2013). Pedoman Nasional Pelayanan Kedokteran Tata Laksana Tuberkulosis. Jakarta.

(Kemenkes RI), Kementerian Kesehatan Republik Indonesia. (2016). Pedoman Nasional Penanggulangan Tuberkulosis Tahun 2016. ; . Jakarta.

Anand, Anil C., \& Hospitals, Indraprastha Apollo. (2015). Risk Factors of Hepatotoxicity During Anti-tuberculosis. . . Medical Journal Armed Forces India., (February), 45-49.

Bil, Janneke P., Schrooders, Peter A. G., Prins, Maria, Kouw, Peter M., Klomp, Judith H. E., Scholing, Maarten, Waegemaekers, CHFM, Zuure, Freke R., \& Tostmann, A. (2018). Screening and prevention of infectious diseases in newly arrived migrants. Integrating hepatitis $B$, hepatitis $C$ and HIV screening into tuberculosis entry screening for migrants in the Netherlands, 2013 to 2015.

Devarbhavi, Harshad. (2012). An update on drug-induced liver injury. Journal of Clinical and Experimental Hepatology, 2(3), 247-259.

Liu, Liying, Qian, Yuan, Zhang, You, Zhao, Linqing, Jia, Liping, \& Dong, Huijing. (2016). Epidemiological aspects of rotavirus and adenovirus in hospitalized children with diarrhea: a 5-year survey in Beijing. BMC Infectious Diseases, 16(1), 508.

Loho, Imelda Maria, \& Hasan, Irsan. (2014). Drug-Induced Liver Injury-Tantangan dalam Diagnosis. Contin. Med. Educ, 41(3), 167-170.

Luthariana, Lies, Karjadi, Teguh H., Hasan, Irsan, \& Rumende, C. Martin. (2017). Faktor Risiko Terjadinya Hepatotoksisitas Imbas Obat Antituberkulosis pada Pasien HIV/AIDS. Jurnal Penyakit Dalam Indonesia, 4(1), 23-28.

Pratiwi, Elsa P., Rohmawaty, Enny, \& Kulsum, Iceu D. (2018). Efek Samping Obat Antituberkulosis Kategori I dan II Pasien Tuberkolosis Paru Dewasa di Rumah Sakit Hasan Sadikin. Indonesian Journal of Clinical Pharmacy, 7(4), 252-259.

Rahayu, Ani. (2018). Analisis Efektifitas Biaya Terapi Anti hipertensi Kombinasi Pada Pasien Hipertensi Di Ruang Rawat Inap RSUD DR. Soekardjo Tasikmalaya. STIKes BTH Tasikmalaya.

Ramappa, Vidyasagar, \& Aithal, Guruprasad P. (2013). Hepatotoxicity related to antituberculosis drugs: mechanisms and management. Journal of Clinical and Experimental Hepatology, 3(1), 37-49.

Reny Setiowati, Dumilah Ayuningtyas. (2017). Failure at The End of DOTS Intensive Phase among Acid Fast Bacilli Positive Pulmonary Tuberculosis. Jurnal 
Respirologi Indonesia, (37), 47-52.

Rifai, Achmad, Herlianto, Budi, Mustika, Syifa, Pratomo, Bogi, \& Supriono, Supriono. (2015). Insiden dan Gambaran Klinis Hepatitis Akibat Obat Anti Tuberkulosis di Rumah Sakit Umum Daerah Dr. Saiful Anwar Malang. Jurnal Kedokteran Brawijaya, 28(3), 238-241.

Saito, Zenya, Kaneko, Yugo, Kinoshita, Akira, Kurita, Yusuke, Odashima, Kyuto, Horikiri, Tsugumi, Yoshii, Yutaka, Seki, Aya, Seki, Yoshitaka, \& Takeda, Hiroshi. (2016). Effectiveness of hepatoprotective drugs for anti-tuberculosis drug-induced hepatotoxicity: a retrospective analysis. BMC Infectious Diseases, 16(1), 1-6.

Savita Mishra, Vidhu Aeri and Deepshikha Pande Katare. (2014). Hepatoprotektor protective Medication For Liver Injury. World Journal and Pharmaceutical Sciences, 5(3), 891-932.

Singh, Charan, Jodave, Laxmikant, Bhatt, Tara Datt, Gill, Manjinder Singh, \& Suresh, Sarasija. (2014). Hepatoprotective agent tethered isoniazid for the treatment of drug-induced hepatotoxicity: Synthesis, biochemical and histopathological evaluation. Toxicology Reports, 1, 885-893.

Sintya, Dewi Ayu. (2018). Efektivitas Penggunaan Obat Hepatoprotektor pada Pasien Tuberkulosis dengan DIH di RSP Dr. M. Goenawan Partowidigdo Cisarua.

Wang, Ning Tao, Huang, Yi Shin, Lin, Meng Hsien, Huang, Bryan, Perng, Chin Lin, \& Lin, Han Chieh. (2016). Chronic hepatitis B infection and risk of antituberculosis drug-induced liver injury: Systematic review and meta-analysis. Journal of the Chinese Medical Association, 79(7), 368-374. 